\title{
Towards Balanced Reciprocity: The Relationship between Landowners and Landless Peasants in the Rural Community
}

\author{
a)Imam Santosa, b) Muslihudin, ${ }^{\text {c)} W i w i e k ~ R . ~ A d a w i y a h ~}$ \\ a)Professor in The Department of Sociology,Faculty of Social and Political Sciences, Jenderal \\ Soedirman University, Purwokerto, Central Jawa, Indonesia 53122 \\ ${ }^{b}$ Associate Professor in The Department of Sociology,Faculty of Social and Political Sciences, \\ Jenderal Soedirman University, Purwokerto, Central Jawa, Indonesia 53122 \\ c)Professor in the Department of Management, Faculty of Economic and Business, Jenderal \\ Soedirman University, Purwokerto, Central Jawa, Indonesia 53122
}

Article History: Received: 10 November 2020; Revised 12 January 2021 Accepted: 27 January

2021; Published online: 5 April 2021

\begin{abstract}
Reciprocity relationships are a necessity in human life. This study aims to describe the various factors that determine the formation of balanced reciprocity in the relationship between land owners and farm laborers. The research's location was determined intentionally in the rural areas of Purbalingga Regency and Banyumas Regency, Central Java Province, Indonesia. This study used a qualitative method with a semi-grounded phenomenological research design. The results showed that a balanced reciprocity relationship was determined by a variety of principal and smoothing factors. The identification results showed that the main determinants include opportunity, benefit, mutual trust, closeness of social relations, motives for reciprocal exchange, openness in communication, willingness to give transactions to accept and return. The array of determinants of smoothing factors is routine contact and communication, empathy, tolerance, length of relationship, regularity of social interactions, network of cooperation, solidarity, transaction ability, mutual control and evaluation. The existence and strength of these two types of determining factors have an important function in the formation of balanced reciprocity among agricultural land owners and farm laborers. Willingness, self-awareness and opportunity are very important to develop to form balanced reciprocity.
\end{abstract}

Keywords: balanced reciprocity, relationships, landowners, peasant community, labour farm

\section{Introduction}

The development of farming communities based on the potential of local resources is one of the conditions for achieving the goals of sustainable agricultural development. Farming communities have various social capitals that need to be managed to accelerate the dynamics of integrated agricultural development (Badaruddin et al., 2018; Mukti \& Wibisono, 2016). One of the social capitals that has an essential function in the development of a farming community is a network of cooperation in productive farm management. In the continuation of the cooperative network of farmer communities, social relations in the form of reciprocity are among the determinants of farmers' performance productivity. The reciprocity that exists between farming communities with different socio-economic status also determines the sustainability of efficient and environmentally friendly farming management (Courtois \& Subervie, 2014; Dumasari et al., 2020). The reciprocal relationship between agricultural land owners and farm laborers is one form of reciprocal exchange that is important to manage in order to lead to symmetrical and balanced cooperation. The adoption of innovations that can increase agricultural production results is smoother when there is mutual trust in a symmetrical and balanced reciprocal bond (Baldassarri, 2015; Weyori et al., 2018). Balanced reciprocity certainly provides economic and social benefits to agricultural land owners and farm laborers.

Reciprocity relationships are an absolute necessity in human life. Therefore, reciprocity relations have become a necessity in social life. The phenomenon of dependence on one another is inevitable so that humans can survive. In the context of balancing the reciprocity relation of rural farming communities, it is characterized by 3 (three) transactions, namely; give and take (Baldassarri, 2015; Hibbard, 1911; Jana et al., 2013). Balanced social exchange causes each actor to obtain benefits to meet needs. Reciprocity relations are formed because there is a common interest. Agricultural land owners need the services of farm laborers to work on farming activities ranging from cultivating land, sowing plant seeds, planting, fertilizing, weeding, controlling pests and harvests. Even farm labour services are also needed for post-harvest activities such as transportation, drying, storage, packaging and 
processing. On the other hand, agricultural laborers need a wage or share of the harvest from the owner of the agricultural land. The reciprocity relationship between the two can last a long time, so that they have a social closeness to help each other. This closeness is not only for farming activities but also for other activities. Reciprocity has the valuable intrinsic value of actual benefits and the value of symbolic communication or the value of reducing the expressiveness and uncertainty conveyed by actions (Molm et al., 2007).

In the case of reciprocity relations, there tends to be a voluntary principle. If it is not managed and controlled, the voluntary principle has the potential to lead to reciprocity leading to unbalanced and asymmetrical symmetry. Voluntary nature with uncertainty traps one party into the trap of being exploited. Individuals who initially benefited one another without a formal or informal agreement took reciprocal actions to convey symbolic value. If so, of course, the actual benefits would be suppressed by the voluntary principle. Of course, the dominance of one party appears as found in our research results which are proven through observations of reciprocity between agricultural land owners and farm laborers in Kutasari and Padamara villages, Purbalingga Regency, Central Java Province, Indonesia (Santosa et al., 2019a, 2020). From the results of this study, it is evident that every asymmetric reciprocal on the one hand benefits, while on the other hand, there are losers. However, the aggrieved party often does not realize that he is weak and at a disadvantage. All actions are carried out on a voluntary basis so that reciprocity has great power to generate altruistic behaviour (Diekmann, 2004). Altruistic behaviour is difficult to erode because it is considered a norm of politeness. In economic relations, reciprocity with the voluntary principle is prone to causing harm to either party. Asymmetric reciprocity relation results in subordinate confusion and intimidation (Breed, 1972; Thomas \& Caillon, 2016; Uhl-bien \& Maslyn, 2003). Development of profitable farm management will, of course, always avoid forms of asymmetrical reciprocity which are dominated by one particular party. Meanwhile, it is known from the findings of research on agricultural land owners and farm laborers in rural Central Java, Indonesia that the creation of a balanced reciprocity relationship is not easy because it is influenced by various determining factors. Flexible reciprocity because every human being who is active as an actor has dynamic movements. The parties involved in reciprocity have an impact on one another. In Homans' observation, a harmonious social life is characterized by a balanced exchange between reward and punishment (Homans, 1974; Santosa et al., 2019b). According to Blau (1974), exchange becomes asymmetrical when it enters the hegemonic element of power, causing social exchange to become less balanced. The nature of the asymmetric relationship among farmers is also influenced by location differentiation (Martínez Valle \& Martínez Godoy, 2019; Santosa et al., 2020). Development of the concept of reciprocity is needed according to the increasingly recent developments in social reality. The reciprocal exchange between landowners and farm laborers attests to the development of a unique variety of forms of reciprocity. The willingness of agricultural landowners to provide access to all agricultural production facilities and means of fertilizers and seeds, including technology in Sumbang, Central Java, demonstrates an agreement towards equality during the production process. Thus, farm workers can focus on farm work. Smallholders and farm laborers show their loyalty to landowners when reciprocity is symmetrical or asymmetrical. The varied forms of reciprocity cannot be separated from the presence of several determinants. The reciprocity between the two of them still faces several problems in order to lead to a balanced state. The problem that tends to arise in reciprocity between farm workers and land owners lies in economic interests. Farm workers' hopes of obtaining benefits or assistance from landowners are often hampered. Cultivators sometimes, in this social context, do not receive adequate wages. As a result, asymmetric reciprocity occurs and is negative and unbalanced. In this case, asymmetric reciprocity is characterized by a stronger bargaining position on the part of farm workers, but there are times and very often the opposite is true (Santosa et al., 2020). This can be understood in the framework of the theory of displacement put forward by Blau (1974) and Marx (1909) according to which the owner of the means of production determines the work relationship. Asymmetric social relations between landowners and farm laborers who live in villages far from urban areas (Han et al., 2017). The various determinants of reciprocity relation towards balance are interesting themes in this study.

\section{Research Methods}

This study used a combination of phenomenological research methods and semi-grounded research. The research design was prepared using a qualitative approach. The use of a qualitative approach is intended to help researchers better understand the subject's personal experience from the point of view of the person concerned (Porter, 1996). The qualitative approach is also intended to keep the researcher from being trapped in stereotypical rigid theoretical thinking. The villages of Kutasari and Padamara in Purbalingga Regency and Kembaran and Sumbang districts in Banyumas Regency, were chosen on purpose as research locations. The two Regencies are part of the Central Java Province, Indonesia. The criteria for selecting the four locations were based on the consideration that in the four sub-districts the conversion rate of agricultural land to non-agricultural uses was high, so it was prone to inequality in land ownership and the number of farm laborers increased. Thus, there are problems regarding the various forms of reciprocity between agricultural land owners and farm laborers. The types of data collected are primary and secondary. Primary data was obtained from informants through in-depth interviews. In-depth 
interviews are carried out based on the structured interview guide. Other primary data collection techniques are utilizing participant observation and focus group discussions. The selected informants are farm laborers. The key informants assigned were land owners, village officials and community leaders. Purposive sampling is used to determine data sources. The number of informants is not proportionally limited to the four research locations. However, the number of informants is adjusted according to the fulfilment of data needs so that they are able to answer the formulation of research problems in a complete and in depth manner. Secondary data was obtained by using documentation analysis technique on several reports and previous research results. Data processing and analysis techniques are carried out qualitatively. The data analysis technique used an interactive model (M.B. Miles and A.M. Huberman, 1991). The Reflection Analysis Model is used to test the relationship between the explanations of each problem statement. The results of the analysis are then interpreted and presented in a sequential descriptive discussion. Data triangulation is used to discover the correctness of information conveyed by informants and key informants through a check and re-check process.

\section{Result And Discussion}

Reciprocity relation is a valuable agreement that has value and strength in various community activities including in farm management (Aminah et al., 2015; Jana et al., 2013; Martínez Valle \& Martínez Godoy, 2019). Various socio-economic characteristics of farmers have different reciprocal relationships in rural areas. There is a condition that is expected when the recipient can take benefits in order to meet needs (Diekmann, 2004). The reciprocity of the farming community is unique. It turns out that the owner of agricultural land is not always the dominant party in reciprocity. Once upon a time, their position changed to being exploited when there was a scarcity of farm laborers. Of course, this stimulates social dynamics. This reality is found in a series of studies. Ideally, the bargaining position of agricultural landowners and farm laborers should be equal and there is a balanced reciprocity so that farm management is maintained for productivity and continuity.

From the beginning, the concept of reciprocity relation was explained as a reciprocal social exchange. Reciprocal social exchange takes place in a transaction that involves participation between the giver and the recipient and then the roles of the two can alternate within a certain time. After a deeper observation of the reciprocity relation incident that took place between agricultural landowners and farm laborers in both Banyumas and Purbalingga villages, it was revealed that the reciprocal process experienced concept development. Reciprocity relation is no longer just an exchange of reciprocity, both give and take. However, the social reality that develops shows the development of the concept of reciprocity that leads to a balanced condition between agricultural landowners and farm laborers who have a transaction to be willing to return something that is received. The process of reciprocity towards balance is observed in Figure 1.

Figure 1. Reciprocity process between land owners and landless peasants

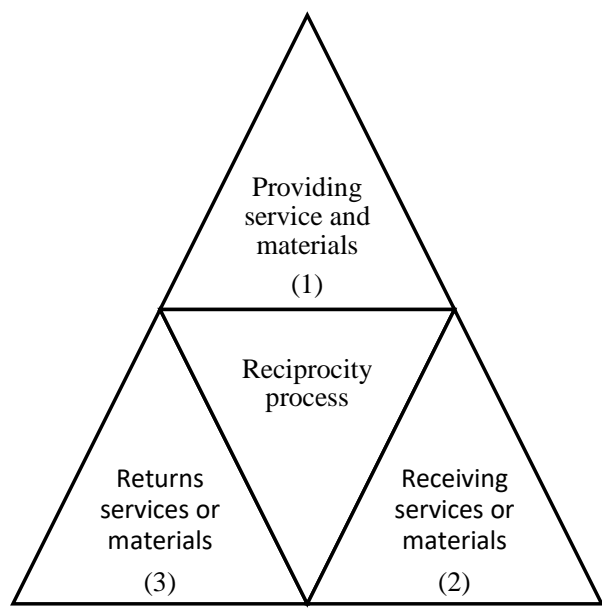

The events of reciprocity relation towards a balance of it that take place between agricultural land owners and farm laborers are formed from the existence of four important elements, namely something to be exchanged, social relations, social interaction, contact and communication. When one of the elements is weak or absent, reciprocity relation is difficult to lead to a balanced condition. Social reality is found that agricultural land owners in Padamara have difficulty forming a balanced reciprocity relation with local farm laborers. These problems are caused by the scarcity of farm laborers in Padamara. Land owners find it difficult to find farm laborers who are faithful in working on their land. The villagers who previously worked as agricultural laborers shifted their livelihoods to non-agriculture. The movement of this movement has been going on since Padamara was developed into a tourist area and a centre for processing plywood (plywood) and other types of industry. 
Farmers who own land look for farm laborers from outside the village. The wages for farm laborers in Padamata are relatively the highest compared to those in Kutasari, Sumbang and Bojongsari. Farm labor wages range from Rp. 70,000 - Rp. 80,000 per day. Meanwhile, the wages for agricultural laborers in Sumbang and Kembaran are between IDR 40,000-IDR 50,000 per day. Farm workers receive the lowest wages in Kutasari, between Rp. 25,000 and Rp. 40,000 per day. The four elements of reciprocity leading to balance are shown in Figure 2.

Figure 2. Toward balanced reciprocity relationship

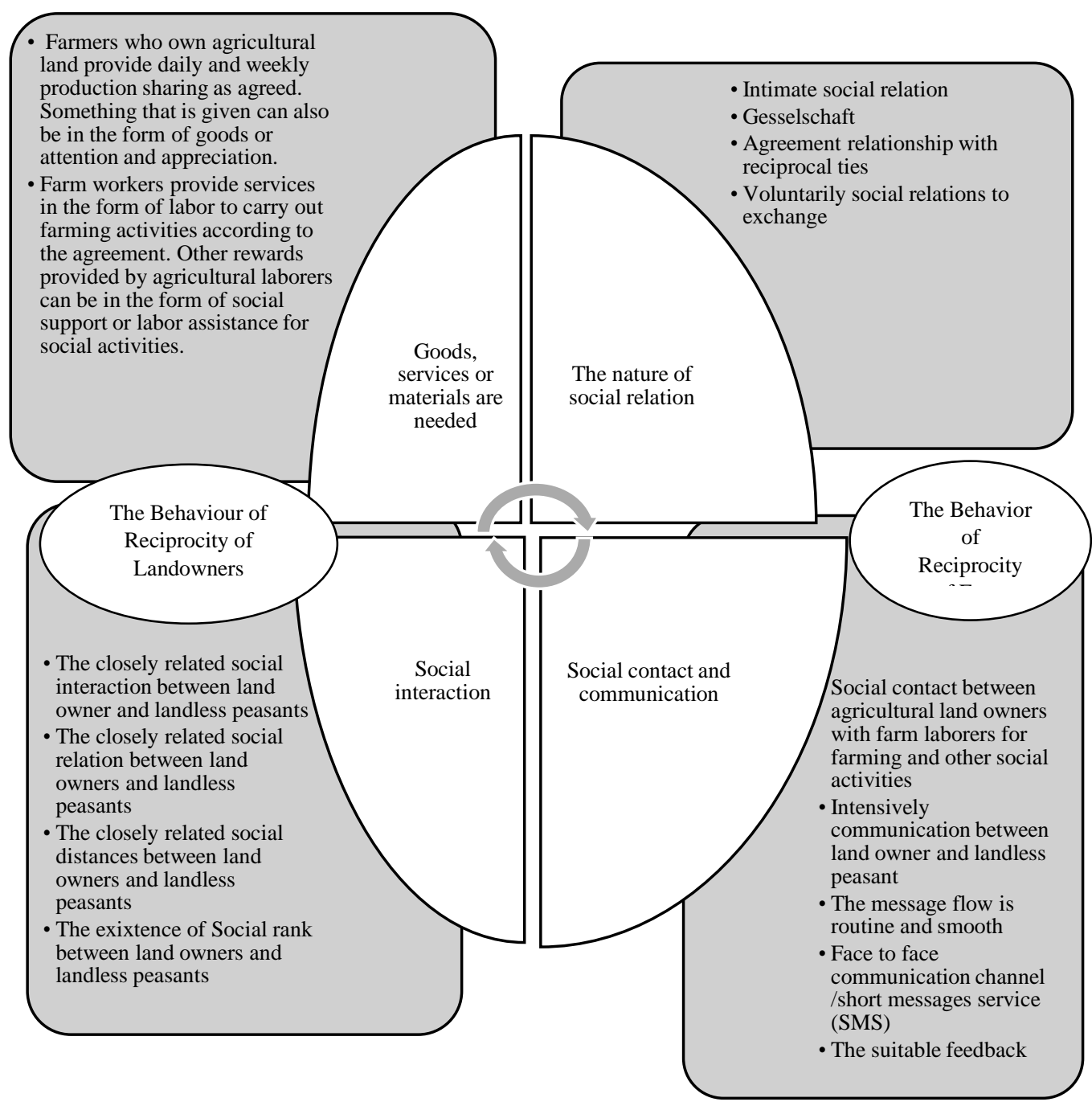

The reciprocity relation that occurs between agricultural land owners and farm laborers can be categorized into four patterns. The four patterns are balanced symmetrical reciprocity, unbalanced symmetrical, asymmetrical with dominant agricultural land owners and asymmetrical with dominant agricultural laborers. Balanced symmetric reciprocity relation was found in the relationship between agricultural land owners and farm laborers in Sumbang. The relationship between the two recipients of reciprocity takes place in an atmosphere of mutual need with economic and social motives. The exchange between the two is aimed at fulfilling mutually beneficial needs. In this social context, there is a harmonious relationship among the parties who practice balanced reciprocity relation. The unequal symmetric reciprocity relation occurs between agricultural land owners and workers in Kembaran. The bargaining position of farm workers is strong due to the scarcity of workers in the agricultural sector. Even so, agricultural land owners always try to adjust the level of wages demanded by farm laborers. Conversely, farm workers show loyalty and performance in accordance with the level of wages received. Their responsibility in managing the farm is high. Even farm workers are willing to irrigate the fields at night. Although not all farm workers are willing to do work hard that is relatively energy-consuming and requires extra attention. 
Asymmetric reciprocity with the dominance of agricultural land owners was found in Kutasari. The bargaining position of farm workers is very weak. Daily wages are determined unilaterally by the owner of the agricultural land. Farm workers can only work for a minimum wage. The provision of services and labor for agricultural land owners is not equal to their wages. This reality seems to show the exploitation of agricultural land owners against agricultural laborers. Perhaps it is because of the difficulties of living the hard work with this imbalanced trade that they do. However, the reciprocal imbalance between the two persists for years. Asymmetric reciprocity with the dominance of agricultural land owners from an economic point of view is still difficult to achieve a balanced condition, however, from a socio-cultural perspective it tends to be considered balanced, because it is inherent in the elements of loyalty, loyalty and patronage (Dumasari, D, Darmawan, W, Iqbal, A, Dharmawan, B, Santosa, 2019). The incidence of asymmetric reciprocity with the domination of farm workers took place in Padamara where the wages were determined by farm workers unilaterally. Agricultural land owners can only agree with it. If the owner tries to bargain for wages, the farm labourer will resign. Such asymmetric reciprocity relation is difficult to achieve a balanced condition. The position of agricultural land owners is as if exploited by farm laborers, eventually there are owners who are then intended to give to employ farm laborers without having to enjoy economic benefits from the land, no one has exploited them. The form of reciprocity between agricultural land owners and farm laborers can be seen in detail in Figure 3.

Figure 3. The condition of reciprocity in four area

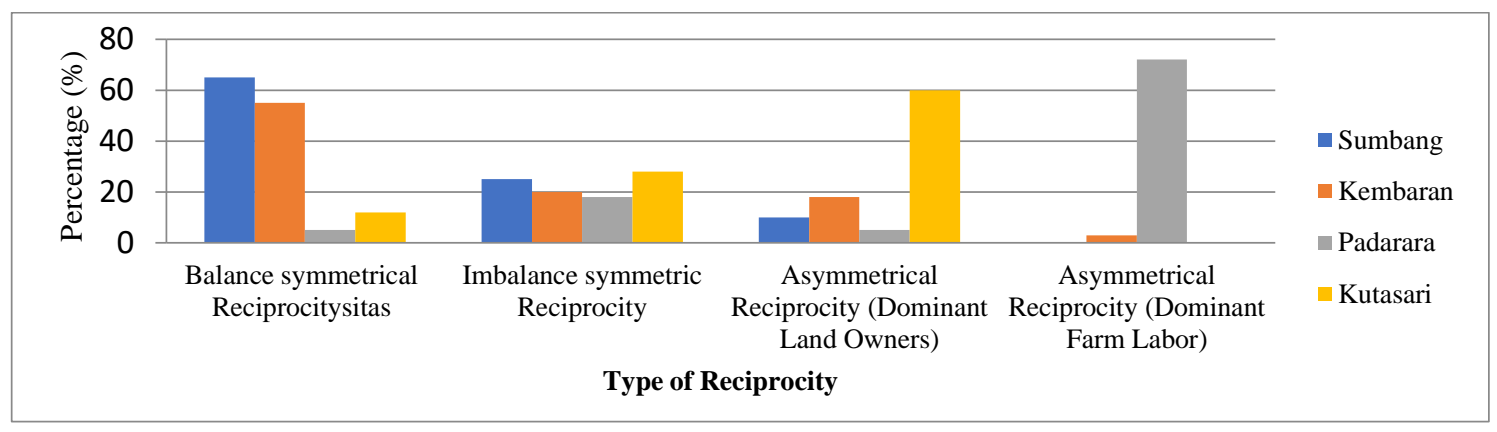

The reciprocal condition of the four areas can be traced from the recorded interviews with several informants: Mr. KN (not his real name) a landowner said:

"In the village of Gandatapa, Sumbang Subdistrict, the harvest sharing is done relatively very fairly. If the land owner bears all the costs of production, yes they can take $75 \%$ of the total yield, but if the tenant wants to get $100 \%$, he must rent the land plus all expenses "

An illustration was also put forward by a cultivator with the initials Mr. TN in Padamara Village, Padamara District

"A farm worker in Padamara Village, Padamara District stated that the land owner doesn't want to know how much I give. If there are a lot of results, I will deposit a lot, if the results are small I will deposit a little. The landowner did not see how many there were. He just believed in me. Yes, we are not related, but we are like brothers. "

The description of the reciprocal relationship can also be traced from a farmer who owns Mr. SNN in Karang Cegak Village, Kutasari District.

"I am quite comfortable here because we still have the remaining results after reducing labor costs and the cost of purchasing production facilities. Here, labor is relatively cheap, working in the morning to evening can be given a fee of Rp. 25,000 - Rp. 50,000"

An overview of the opinion poll from informants can be traced to Bojongsari Village, Kembaran District from Mr. GMN (not his real name)

"A farmer owner said that the labor wages are relatively high here. In general, there is no maro (for two) or mertelu (for three) systems, almost all the land is leased. Not to mention, workers don't want to be paid low, so luckily our children and nieces can help. If we pay high, right for you, no problem. So we are able to reduce price of production" 
The form of balanced reciprocity relation between agricultural land owners and farm laborers in Sumbang and Kembaran is in fact influenced by a determining factor. Some of the various determinants are of a primary nature and some of them are of a seamless nature. The principal determinants have the power to form balanced reciprocity. Among the determinants referred to are, among others: usefulness, mutual trust, social closeness, motives for reciprocal exchange, openness in communication, willingness to give, receive and return as well as the opportunity factor. Some of the main determining factors can be seen in Figure 4.

Figure 4. Variety of determining factors of the balanced reciprocity relation

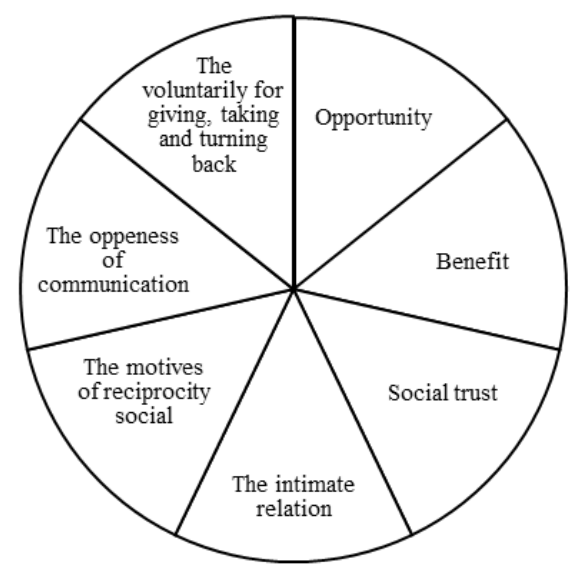

Balanced reciprocity relation among agricultural land owners and agricultural laborers in Sumbang and Kembaran is formed by several facilitating factors. The existence of a smoothing factor is not essential to create a balanced condition. It's just that the determining factors facilitate and accelerate the formation of a balanced reciprocity relation between agricultural land owners and farm laborers. Details about the various determinants of success are listed in Figure 5.

Figure 5. The variety of smothing determining factors of balanced reciprocity



The concept of reciprocity relation is a valuable social capital that needs to be managed and utilized to harmonize social relations between agricultural land owners and farm laborers. The harmonization of reciprocal exchanges achieves a balanced condition if each one that is exchanged provides mutual benefits. Something that is exchanged, whether services, goods or materials, is not measured in terms of quantity alone, but rather than its usefulness in meeting the needs of agricultural land owners and farm laborers in managing farm businesses. Several principal and smoothing determinants make a meaningful contribution to achieving balanced reciprocity. The relationship between these determinants and the process of balanced reciprocity can be seen in Figure 6 . 
Figure 6. Variety of Balanced Reciprocity Determinants

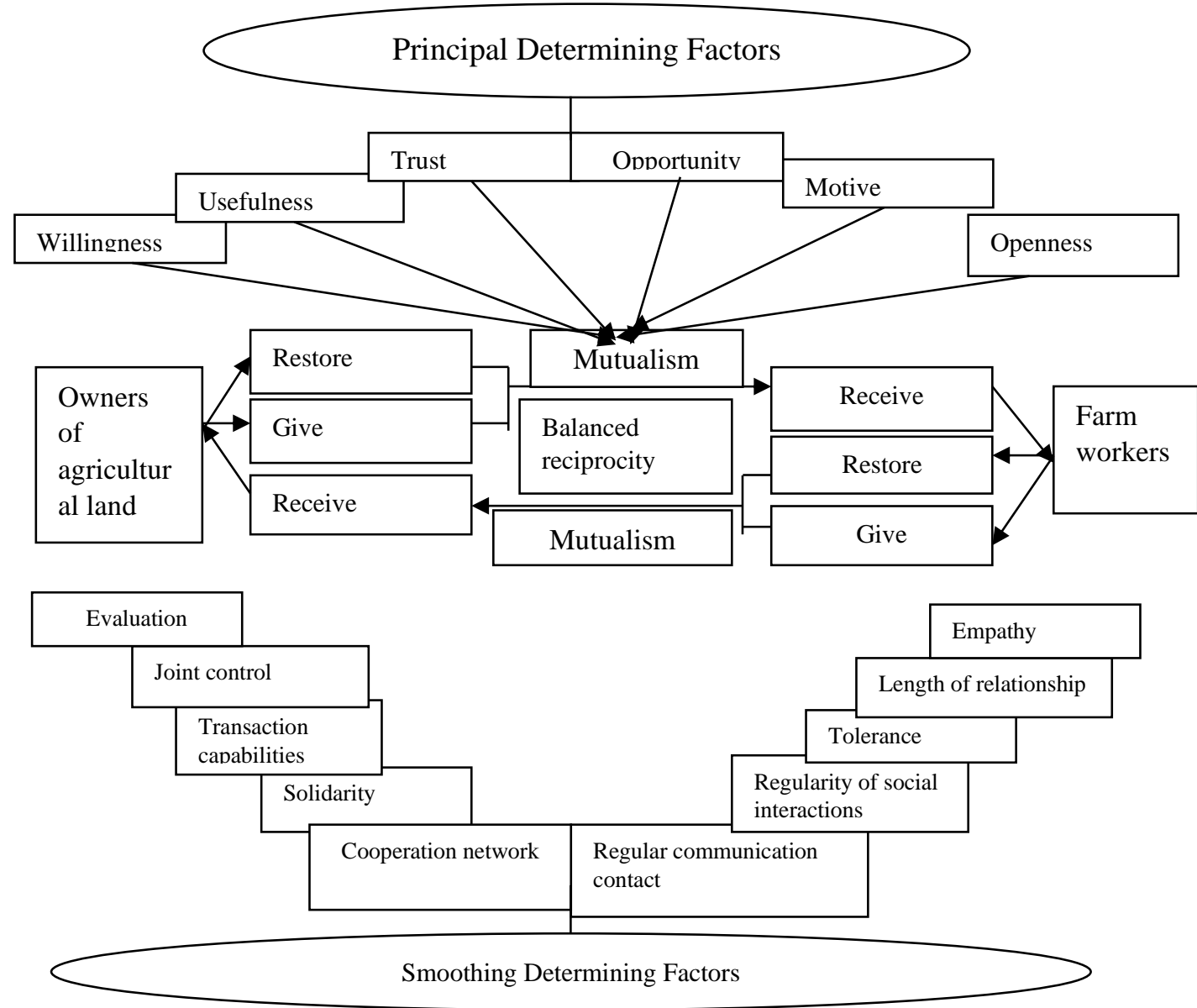

\section{Conclusion and recommendation}

It turns out that the development of the concept of reciprocity relation does not only involve giving and receiving transactions between parties with mutual interests to meet needs. The results showed that the process of reciprocity in order to be ready to be balanced cannot be separated from the willingness to give, receive and return. Balanced reciprocity relation is formed when it has four elements, namely something that is exchanged, available social relations, contact and communication and social interaction. Balanced reciprocity between agricultural land owners and farm laborers is built on the strength of the main and facilitating factors. Details of the main determining factors include opportunity, benefit, mutual trust, closeness of social relations, motives for reciprocal exchange, openness in communication, willingness to be willing to give transactions to give back. The determinants of smoothing are routine contact and communication, empathy, tolerance, length of relationship, regularity of social interactions, network of cooperation, solidarity, transaction ability, joint control and evaluation. These two types of determinants have a causal relationship in the balanced reciprocity that exists between agricultural land owners and farm laborers. The balanced concept of reciprocity is characterized by the transaction of giving, receiving and returning, each actor receiving benefits to meet his needs. Reciprocity which is still difficult to be balanced conceptually can be managed by strengthening the function of each main determining factor and facilitating factor. so that the willingness and opportunity of the two actors need to be developed with self-awareness to be willing to give, receive and return.

\section{Acknowledgement}

The research's team is very grateful to Directorate Research and Social Services (Direktorat Riset dan Pengabdian Kepada Masyarakat (DRPM) for providing research funding. Without their contribution, this research would not have been possible. The team also deeply thanks the farm laborers, owner farmers, village officials and rural community leaders in Purbalingga and Banyumas Regency, Central Jawa Province who agreed to be interviewed as informants and also participated in the Focus Group Discussion (FGD). 


\section{References}

[1]. Aminah, S., Sumardjo, Lubis, D. P., \& Susanto, D. (2015). Factors affecting peasants' empowerment in West Halmahera District - A case study from Indonesia. Journal of Agriculture and Rural Development in the Tropics and Subtropics, 116(1), 11-25.

[2]. Badaruddin, D., Kariono, K., Ermansyah, D., \& Sudarwati, L. (2018). Community empowerment based social capital and village business company (BUMDes). Advances in Social Science, Education and Humanities Research, 136(6), 181-187. https://doi.org/10.2991/icosop-17.2018.27

[3]. Baldassarri, D. (2015). Cooperative networks: Altruism, group solidarity, reciprocity, and sanctioning in ugandan producer organizations. American Journal of Sociology, 121(2), 355-395. https://doi.org/10.1086/682418

[4]. Blau, P. M. (1974). Presidential address: Parameters of social structure. American Sociological Review, 39(5), 615-635.

[5]. Breed, G. (1972). The effect of intimacy: Reciprocity or retreat? The British Journal of Social and Clinical Psychology, 11(2), 135-142. https://doi.org/10.1111/j.2044-8260.1972.tb00794.x

[6]. Courtois, P., \& Subervie, J. (2014). Farmer bargaining power and market information services. American Journal of Agricultural Economics, 97(3), 953-977. https://doi.org/10.1093/ajae/aau051

[7]. Diekmann, A. (2004). The power of reciprocity: Fairness, reciprocity, and stakes in variants of the dictator game. Journal of Conflict Resolution, 48(4), 487-505. https://doi.org/10.1177/0022002704265948

[8]. Dumasari, D, Darmawan, W, Iqbal, A, Dharmawan, B, Santosa, I. (2019). Development of production creativity among craftsmen by identifying techniques for characterizing coconut waste. International Journal on Advanced Science, Engineering and Information Technology, 9(2), 717-723. https://doi.org/10.18517/ijaseit.9.2.5871

[9]. Dumasari, Darmawan, W., Ismangil, Dharmawan, B., \& Santosa, I. (2020). Empowerment of subsistence craftsmen through the adoption of environmentally friendly cocodust production technology. International Journal on Advanced Science, Engineering and Information Technology, 10(2), 691-702. https://doi.org/10.18517/ijaseit.10.2.8522

[10]. Han, L., Bao, H., \& Peng, Y. (2017). Which factors affect landless peasants intention for entrepreneurship ? A case study in the south of the yangtze river Delta, China. Sustainability, 9(1158), 118. https://doi.org/10.3390/su9071158

[11]. Hibbard, B. H. (1911). Reciprocity and The Farmer. In The American Economic Review (Vol. 1, Issue 2, pp. 221-233).

[12]. Homans, G. C. (1974). Social behavior: Its elementary forms, Revised ed. In Social behavior: Its elementary forms, Revised ed. Harcourt Brace Jovanovich.

[13]. Jana, R., Bandyopadhyay, S., \& Choudhuri, A. K. (2013). Reciprocity among farmers in farming system research: Application of social network analysis. Journal of Human Ecology, 41(1), 45-51. https://doi.org/10.1080/09709274.2013.11906552

[14]. M.B. Miles and A.M. Huberman. (1991). Designing Qualitative Research. https://doi.org/10.7748/ns.30.25.33.s40

[15]. Martínez Valle, L., \& Martínez Godoy, D. (2019). Territorial dynamics and social differentiation among peasants in the northern highlands of Ecuador. Journal of Agrarian Change, 19(4), 635-653. https://doi.org/10.1111/joac. 12322

[16]. Marx, K. (1909). Capital: A Critique of Political Economy. In Chicago: Charles H. Kerr and Co. Libery Fund

Inc. http://scholar.google.com/scholar?hl=en\&btnG=Search\&q=intitle:Enquiries+Concering+Human+Uderst anding\#1

[17]. Molm, L. D., Schaefer, D. R., \& Collett, J. L. (2007). The value of reciprocity. Social Psychology Quarterly, 70(2), 199-217. https://doi.org/10.1177/019027250707000208

[18]. Mukti, G., \& Wibisono, A. (2016). Strategy of strengthening social capital of farmer group in agricultural development. JEJAK: Jurnal Ekonomi Dan Kebijakan, 9(1), 61-80. https://doi.org/10.15294/jejak.v9i1.6655

[19]. Porter, M. E. (1996). What is Strategy. In Harvard Buisness Review OnPoint (Vol. 74).

[20]. Santosa, I., Muslihudin, \& Adawiyah, W. R. (2020). Changes in reciprocity: From patron - client relationships to commercial transactions in rural Central Java. International Journal of Innovation, Creativity and Change, 14(4), 846-858.

[21]. Santosa, I., Muslihudin, M., \& Adawiyah, W. R. (2019a). Current form of reciprocity between land owners peasant and peasant laborer. Journal of Arts and Humanities, 8(8), 53-59. https://doi.org/10.18533/journal.v8i8.1725

[22]. Santosa, I., Muslihudin, M., \& Adawiyah, W. R. (2019b). Current form of reciprocity between land owners peasant and peasant laborer. Journal of Arts and Humanities, 8(8), 53-59. 
https://doi.org/10.18533/journal.v8i8.1725

[23]. Thomas, M., \& Caillon, S. (2016). Effects of farmer social status and plant biocultural value on seed circulation networks in Vanuatu. Ecology and Society, 21(2). https://doi.org/10.5751/ES-08378-210213

[24]. Uhl-bien, M., \& Maslyn, J. M. (2003). Reciprocity in manager-subordinate relationships: Components, configurations, and outcomes. Journal of Management, 29(4), 511-532. https://doi.org/10.1016/S01492063

[25]. Weyori, A. E., Amare, M., Garming, H., \& Waibel, H. (2018). Agricultural innovation systems and farm technology adoption: Findings from a study of the Ghanaian plantain sector. Journal of Agricultural Education and Extension, 24(1), 65-87. https://doi.org/10.1080/1389224X.2017.1386115 